\title{
Review of Post-Mandarin Masculinity and Aesthetic Modernity in Colonial Vietnam-ERRATUM
}

Judith Henchy

Doi:10.1017/pli.2018.12. Published by Cambridge University Press, August 30, 2018.

The original files for both the online and print versions of this article were corrupted. The online version has been replaced in its entirety. Cambridge University Press apologizes to the author and readers for this error.

The correct version of the text is reprinted here.

\section{Book review}

\author{
Post-Mandarin Masculinity and Aesthetic Modernity in Colonial Vietnam \\ By BEN TRAN \\ Fordham University Press, 2017, 178 pp. \\ doi:10.1017/pli.2018.12
}

In Post-Mandarin Masculinity and Aesthetic Modernity in Colonial Vietnam, Ben Tran explores how European literary tropes associated with modernism were adapted by Vietnamese literati to consciously craft a gendered national subjectivity under late French colonialism. This is a significant contribution to our understanding of a Vietnamese social and intellectual world at a moment of transition from Confucian to European social and intellectual habits. Tran's innovation is a focus on gender that places masculine anxieties of modernizing change at the very heart of an emergent Vietnamese national consciousness. Taking Benedict Anderson's formulations of print capitalism as a foundational condition of possibility for a modern national subjectivity-in dialogue with philosopher Jacques Rancière-Tran explores how the narrative modalities that emerged in the 1930s invoked gender in the formation of this subjectivity through the prosaic enunciation of everyday life in which feminine concerns were dominant. Women in these narrations are not only a mime for colonial subjugation - as prostitutes and me tây (women who marry a Westerner) - but also as a locus of a contested modern autonomy and a new reading public that challenged Confucian norms of masculine address: "[w] omen are excluded from yet revealingly frame the process of modernization" (87).

The post-Mandarin intellectual in this discussion found his homosocial Confucian world fragmented, with Confucian learning diminished but its gendered value 
systems upheld. Tran shows how this crisis of masculinity resulted in literary productions of unstable gender identities and fractured narrative voices, which he detects in the new forms of reportage, fictional realism, and novels. He sees realist reportage [phóng sự] as promoting national consciousness through the autonarration of a national culture, but also as a means for male authors to define the self through "engagement with a female other," (25) usually pathologizing women as objects of colonial desire. The "pornographic" realist novelist and satirist Vũ Trọng Phụng elides this realism with novelistic form, while in the "sociological novels" of the Tư Lực Văn Đoàn [Self-Strengthening Group], Tran sees European modes of critical reflection and modern sociology used to analyze Confucian norms in ways that challenge the subaltern studies group's presumptions about the role of tradition in colonial modernity.

Citing Rancière's “democratization of language," Tran notes: “The imagination of the nation is not technologically determined but rather is prosaically determined" (50), arguing against Anderson's focus on the enabling techne of print culture in favor of the narrative itself as a "reconfigured systems of representation" and a condition of modernity (122). Looming large in the emerging national imaginary at this time, however, is not only the notion of simultaneity cited by Anderson, but a proliferation of imagery, which Tran mentions only briefly in relation to an illustration accompanying a work of reportage. Perhaps Tran's privileging of the prosaic too easily forecloses on the complexities of print culture as a technology, as Rancière himself explores in his critique of Walter Benjamin's formulations on mechanical reproduction in the democratization of the aesthetic. Tran also addresses the related Art for Life's Sake polemic, focusing on André Gide not for his engaged literature, but as a bearer of a subverted masculinity that permitted a post-Mandarin homoeroticism. Gide's transgressive sexuality suggested a non-normative subjectivity that could break with Western intellectual practices-escaping the bind of Franz Fanon's trap of colonial mimesis and the subaltern studies postcolonial reinscription of colonial power. Despite the vigor of this polemic, Tran perceptively concludes that the debate over literature's social function, which was enthusiastically joined by Marxists keen to promote the primacy of class, was "never about the autonomy of art but how literature would affect, address, and shape the reading masses" (118).

Basing modernity firmly on the "aesthetic sovereignty of literature," Tran's work occupies an ambivalent position in relation to historical scholarship. His work addresses Peter Zinoman's political biography of Vũ Trọng Phụng, but he engages sparingly with Martina Nguyen's work on the Tự Lực Văn Đoàn and other work addressing the material conditions for the feminizing of modernity under colonialism-where the European women's rights movement, fashion, family hygiene, and so on were already aestheticized in various competing constructions. The (feminized) colonial imaginary was attributable to various contending discourses, including the influential Phu N $\tilde{\mathcal{u}}$, Tân Văn [Ladies Journal], and other women's journals that featured women's voices, including the poet, activist, and journalist Nguyền Thị Kiêm, an eloquent proponent of women in literature. Nevertheless, in a theoretically engaged work, Tran provocatively questions the nature of an autonomous aesthetic modernity under conditions of 
colonialism and its ability to represent beyond the constraining epistemologies of both tradition and instrumental reason.

JUDITH HENCHY

University of Washington

judithh@uw.edu

\section{Reference}

Judith Henchy. Review of Post-Mandarin Masculinity and Aesthetic Modernity in Colonial Vietnam, The Cambridge Journal of Postcolonial Literary Inquiry 5 (2018) 424-426. 